\title{
Nursing diagnoses related to skin: operational definitions
}

\author{
Maria Andréia Silva Ribeiro ${ }^{1}$ \\ Julieth Santana Silva Lages ${ }^{2}$ \\ Maria Helena Baena Moraes Lopes ${ }^{3}$
}

\begin{abstract}
Objective: to validate the operational definitions of the defining characteristics and risk factors of the three NANDA International (NANDA-I) nursing diagnoses and to revise these diagnoses' definitions. Method: content validation of nursing diagnosis. 146 defining characteristics and risk factors were identified in the literature in Brazilian and international databases. This was followed by content validation of the definitions of these diagnoses (presented by NANDA-I) and of the operational definitions (developed by the researchers) of the defining characteristics and risk factors, carried out by six expert nurses, regarding relevance, clarity and comprehensiveness. Result: of the 146 defining characteristics and risk factors, 22 were considered redundant and were excluded. The experts proposed changing the definitions of the diagnoses of Impaired Tissue Integrity and Risk for Impaired Skin Integrity. It was possible to identify various defining characteristics and risk factors which are not present in the NANDA-I taxonomy but which are indicated in the literature. Conclusion: the process attained its objective of producing valid operational definitions for defining characteristics and risk factors, which will permit the undertaking of validation studies for these diagnoses. The study's contribution to advancing scientific knowledge consists in its presenting clearer operational definitions for these diagnoses and a higher number of defining characteristics and risk factors, which will assist the nurses in the identification and use of the same with greater accuracy in clinical practice.
\end{abstract}

Descriptors: Nursing; Nursing Diagnosis; Validation Studies.

\footnotetext{
${ }^{1}$ RN, Hospital Municipal Dr. Mário Gatti, Campinas, Brazil. Doctoral Student, Departamento de Enfermagem, Faculdade de Ciências Médicas, Universidade Estadual de Campinas, Brazil.

2 Undergraduate student in nursing, Departamento de Enfermagem, Faculdade de Ciências Médicas, Universidade Estadual de Campinas, Brazil. ${ }^{3}$ PhD, Associate Professor, Departamento de Enfermagem, Faculdade de Ciências Médicas, Universidade Estadual de Campinas, Brazil.
} 


\section{Diagnósticos de enfermagem relacionados à pele: definições operacionais}

Objetivo: validar as definições operacionais das características definidoras e fatores de risco dos três diagnósticos de enfermagem, relacionados à pele, da NANDA International (NANDA-I), e revisar as definições desses diagnósticos. Método: validação de conteúdo de diagnóstico de enfermagem. Identificaram-se 146 características definidoras e fatores de risco na literatura, nas bases de dados nacionais e internacionais. Em seguida, realizou-se a validação de conteúdo das definições desses diagnósticos, apresentadas pela NANDA-I e das definições operacionais, elaboradas pelas pesquisadoras, das características definidoras e fatores de risco, por seis enfermeiras peritas, quanto à pertinência, clareza e abrangência. Resultados: das 146 características definidoras e fatores de risco, 22 foram considerados redundantes e excluídos. Os peritos propuseram mudar a definição dos diagnósticos de Integridade Tissular Prejudicada e Risco de Integridade da Pele Prejudicada. Foi possível identificar várias características definidoras e fatores de risco que não estão presentes na taxonomia da NANDA-I, mas que foram apontados pela literatura. Conclusão: o processo atingiu o objetivo de produzir definições operacionais válidas para características definidoras e fatores de risco, o que permitirá realizar estudos de validação desses diagnósticos. A contribuição do estudo para o avanço do conhecimento científico consiste em apresentar definições operacionais mais claras desses diagnósticos e número maior de características definidoras e fatores de risco que poderão contribuir para que os enfermeiros identifiquem e se utilizem dos mesmos com maior acurácia na prática clínica.

Descritores: Enfermagem; Diagnóstico de Enfermagem; Estudos de Validação.

\section{Diagnósticos de enfermería relacionados a la piel: definiciones operacionales}

Objetivo: validar las definiciones operacionales de las características definidoras y factores de riesgo de los tres diagnósticos de enfermería relacionados a la piel de la NANDA International (NANDA-I) y revisar las definiciones de eses diagnósticos. Método: validación de contenido de diagnóstico de enfermería. Se identificaron 146 características definidoras y factores de riesgo en la literatura en las bases de datos nacionales e internacionales. Enseguida, se realizó la validación de contenido de las definiciones de estos diagnósticos, presentadas por la NANDA-I y de las definiciones operacionales, elaboradas por las investigadoras, de las características definidoras y factores de riesgo, por seis enfermeras expertas, en cuanto a la pertinencia, clareza y abarcamiento. Resultado: de las 146 características definidoras y factores de riesgo, 22 fueron considerados redundantes y excluidos. Los peritos propusieron alterar la definición de los diagnósticos de Integridad Tisular Dañada y Riesgo de Integridad de la Piel Dañada. Fue posible identificar varias características definidoras y factores de riesgo que no están presentes en la taxonomía de la NANDA-I, pero, que fueron apuntados por la literatura. Conclusión: el proceso alcanzó el objetivo de producir definiciones operacionales válidas para características definidoras y factores de riesgo, lo que permitirá realizar estudios de validación de estos diagnósticos. La contribución del estudio para el avance del conocimiento científico consiste en presentar definiciones operacionales más claras de estos diagnósticos y un número mayor de características definidoras y factores de riesgo que podrá aportar con los enfermeros en la identificación y utilización de los mismos con mayor precisión en la práctica clínica.

Descriptores: Enfermería; Diagnósticos de Enfermería; Estudios de Validación.

\section{Introduction}

Research in the area of nursing has grown significantly in recent decades, including on Nursing Diagnoses (ND). Validation of nursing diagnoses comprises the degree to which a group of defining characteristics describes a reality which may be observed in the client-environment interaction ${ }^{(1)}$.
Various validation methods exist, among which are three models set out by Fehring(2) which are: Diagnostic Content Validation (DCV), Clinical Diagnostic Validity (CDV) - and Differential Diagnostic Validation (DDV). These methods are still the most used.

Publications about diagnostic validation intensified 
in the 1990's, due to greater concern about improving and legitimating the diagnoses described in the NANDAInternational Taxonomy (NANDA-I) ${ }^{(3)}$.

The NANDA-I ${ }^{(4)}$ describes three nursing diagnoses related to the skin: Impaired Skin Integrity and Risk for Impaired Skin Integrity, approved in 1975, and Impaired Tissue Integrity, approved in 1986. These were last updated in 1998.

The principle international studies on the validation of these diagnoses occurred in the 1990s. In Brazil, there are several publications describing and discussing the presence, incidence and prevalence of these diagnoses, their defining characteristics (DCs), risk factors (RFs) and related factors, but until recently there were no validation studies.

Bear in mind that defining characteristics are observable indications/inferences which may be grouped as manifestations of an actual ND or of wellbeing, and that risk factors are environmental factors and physiological, psychological, genetic or chemical elements which increase the vulnerability of an individual, family or community to an unhealthy event ${ }^{(4)}$.

In 2010 and 2011, two master's degree dissertations were published on diagnoses of Impaired Tissue Integrity and Impaired Skin Integrity. One was about validation, and the objective of the other was to verify the occurrence of these diagnoses in patients with vasculogenic ulcers ${ }^{(5-6)}$.

No studies were found addressing the validation of the three diagnoses together, with discussion about each's definition and scope. In addition, the two most recent studies explored - in a way which would describe these diagnoses better - few defining characteristics and risk factors reported in the literature other than those described in the NANDA-I taxonomy. Accordingly, if nurses are to be offered scientific support to facilitate the use of these diagnoses in their clinical practice, it is necessary to develop studies addressing this issue.

Before carrying out any study on validation, a literature review is recommended, to provide theoretical support, both for the diagnoses and the DCs/ RFs, benefitting the development of the operational definitions $^{(2)}$.

Based on these considerations, the authors' proposal was to validate the operational definitions of the DCs and RFs of the skin-related nursing diagnoses in NANDA-I described in the literature and to revise these diagnoses' definitions, that is, to ascertain if these diagnoses are appropriate and, if necessary, to propose new definitions.

\section{Method}

This was methodological research, on the content validation of DCs/RFs of the diagnoses of Impaired Skin Integrity, Risk for Impaired Skin Integrity and Impaired Tissue Integrity.

The period researched included the publications on the issue from 1975 until March 2009, as it was in 1975 that the diagnoses of Impaired Skin Integrity and Risk of Impaired Integrity were approved by NANDA-I.

To identify what the DCs/RFs of these diagnoses were, a bibliographic survey was undertaken in Brazilian and international health databases, namely: the Latin American and Caribbean Center on Health Sciences Information (LILACS), Brazilian Nursing databank (BDENF), Medical Literature Analysis and Retrieval System Online (Medline), the State University of São Paulo's bibliographic database (Dedalus), the National Library of Medicine and the National Institute of Health (Pubmed), the Cumulative Index to Nursing Allied Health Literature (Cinahl) and also the library system of the University of Campinas (SBU).

The NANDA-I periodical, currently termed the International Journal of Nursing Knowledge, but formerly known as Nursing Diagnoses, was also consulted.

Further, research was carried out manually by reading the titles and abstracts in the proceedings of the NANDA-I conferences held in Brazil, and in the Annals of the National Symposiums on Nursing Diagnoses (Sinadens) which were arranged and made available by the Brazilian Association of Nursing (ABEn). Two books on nursing diagnoses, both considered classics, were also used ${ }^{(4,7)}$.

The survey was undertaken with the following descriptors, using the Boolean operator AND: diagnóstico de enfermagem/nursing diagnosis AND estudos de validação/validation studies, as recommended in the list of Descriptors in Health Sciences (DeCS) of the Regional Library of Medicine (Bireme) and in the list of Medical Subject Headings (MeSH) of the National Library of Medicine (NLM).

In addition to these descriptors, the following terms were used: diagnosis validation, nursing diagnosis of Impaired Skin Integrity, nursing diagnosis of Risk for Impaired Skin Integrity, and nursing diagnosis of Impaired Tissue Integrity.

The inclusion criteria for the selection of articles found in the databases were: to be an article about nursing diagnosis which involves the process of validation, or which describes the DCs/RFs of at least one 
of the three diagnoses researched, and to be available, in full, either online or in printed form. As shown in
Figure 1 , after reading the texts in their entirety, 36 articles were selected.

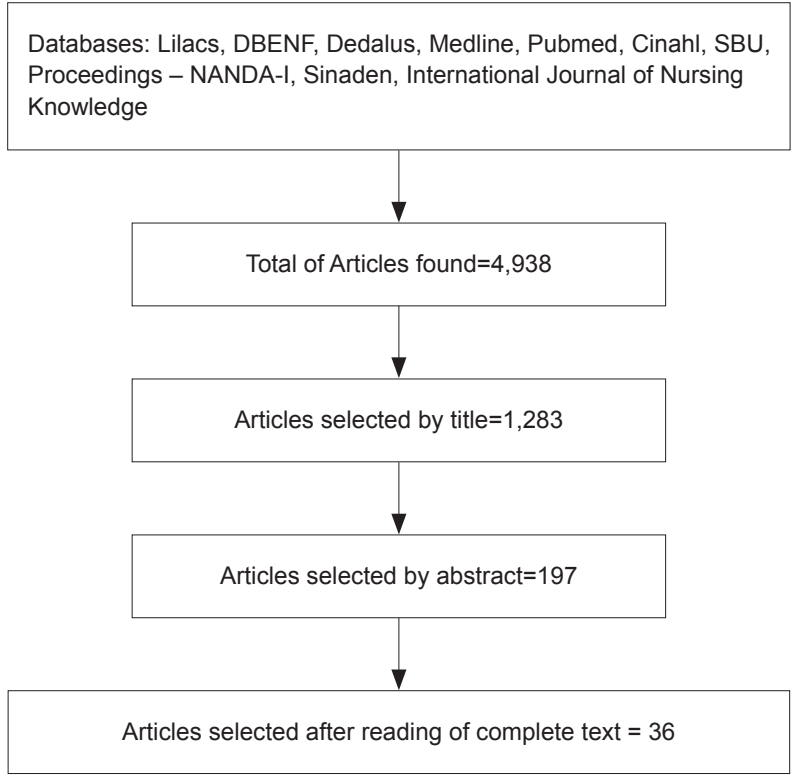

Figure 1 - Summary of the search for articles in the literature review

\begin{tabular}{|c|c|}
\hline Articles, authors, periodicals & DCs/RFs - diagnosis \\
\hline $\begin{array}{l}1 \text { - Carpenter-Iverson M. A descriptive study of the etiologies and defining characteristics of pressure sores. In: } \\
\text { Carroll-Johnson RM; J.B. Lippincott Classification of nursing diagnoses: proceedings of the eighth conference } \\
\text { held in St. Louis, MO, March, 1988. St. Louis,1989. p 275-80. }\end{array}$ & Impaired Skin Integrity (DC) \\
\hline 2 - Iverson-Carpenter MS. Impaired skin integrity. Journal of Gerontological Nursing.1988;14(3):25-9. & Impaired Skin Integrity (DC) \\
\hline $\begin{array}{l}3 \text { - Levin RF, Krainovitch BC, Bahrenburg E, Mitchell CA. Diagnostic content validity of nursing diagnoses. } \\
\text { Image J Nurs Sch.1989; 21(1): 40-4. }\end{array}$ & Impaired Skin Integrity (DC) \\
\hline $\begin{array}{l}4 \text { - Schappler N. Impaired skin integrity: actual and potential in orthopedic patients. In: Carroll-Johnson RM; } \\
\text { J.B. Lippincott. Classification of nursing diagnoses: proceedings of the eighth conference held in St. Louis, } \\
\text { MO, March, 1988. 1989. p. 345-8. }\end{array}$ & Impaired Skin Integrity (DC/RF) \\
\hline $\begin{array}{l}5 \text { - Schue RM, Langemo DK. Pressure ulcer prevalence and incidence and a modification of the Braden Scale } \\
\text { for a rehabilitation unit. J Wound Ostomy Continence Nurs. 1998; 25(1): 36-43. }\end{array}$ & Impaired Skin Integrity (RF) \\
\hline $\begin{array}{l}6 \text { - Hardy MA. A pilot study of the diagnosis and treatment of impaired skin integrity: dry skin in older persons. } \\
\text { Nursing Diagnosis. 1990;1(2):57-63. }\end{array}$ & Impaired Skin Integrity (DC) \\
\hline $\begin{array}{l}7 \text { - Anderson J, Thomson A. Impaired skin integrity: clinical validation of the defining characteristics. In: Carroll- } \\
\text { Johnson RM; J.B. Lippincott. Classification of nursing diagnoses: proceedings of the ninth conference held in } \\
\text { Orlando, FL, 1990. Orlando. } 1991 \text { p.126-32. }\end{array}$ & Impaired Skin Integrity (DC) \\
\hline $\begin{array}{l}8 \text { - Lewis-Abney K, Rosenkranz CF. Content validation of impaired skin integrity and urinary incontinence in } \\
\text { the home health setting. Nurs. Diag.1992; 5(1):36-42. }\end{array}$ & Impaired Skin Integrity (DC) \\
\hline $\begin{array}{l}9 \text { - Piloian BB. Defining characteristics of the nursing diagnosis "high risk for impaired skin integrity". } \\
\text { Decubitus: The Journal of Skin Ulcers.1992; 5(5): 32-47. }\end{array}$ & Impaired Skin Integrity (RF) \\
\hline $\begin{array}{l}10 \text { - Sparks SM. Nurse validation of pressure ulcer risk factors for a nursing diagnosis. Decubitus The Journal } \\
\text { of Skin Ulcers.1992; 5(1): 26-35. }\end{array}$ & Impaired Skin Integrity (RF) \\
\hline $\begin{array}{l}\text { 11 - Sparks SM. Clinical validation of pressure ulcer risk factors. Ostomy Wound Management. 1993; 39(4):40- } \\
51 .\end{array}$ & Impaired Skin Integrity (RF) \\
\hline $\begin{array}{l}12 \text { - Wieseke A; Twibell KR; Bennett S; Marine M; Schoger J. A content validation study of five nursing } \\
\text { diagnoses by critical care nurses. Heart \& Lung.1994; } 23(4): 345-51 .\end{array}$ & Impaired Skin Integrity (DC) \\
\hline $\begin{array}{l}13 \text { - Digloria- Harness- D. Charles G. Risk for Impaired Skin Integrity: Incorporation of the Risk Factors from } \\
\text { AHCPR Guidelines classification of nursing diagnoses: proceeding of the eleventh conference/North American } \\
\text { Nursing Diagnosis Association. Nashville. March 1994. p 204-08. }\end{array}$ & Risk of Impaired Skin Integrity (RF) \\
\hline $\begin{array}{l}14 \text { - Pasini D, Alvim I, Kanda L, Mendes RSP, Cruz, DALM. Diagnósticos de enfermagem de pacientes em } \\
\text { unidades de terapia intensiva. Rev. esc. enferm. USP.1996; 30(32):501-18. }\end{array}$ & Impaired Skin Integrity (DC) \\
\hline $\begin{array}{l}15 \text { - Cesaretti IUR. Dermatite periestoma: da etiologia ao tratamento e assistência de enfermagem. Acta paul. } \\
\text { enferm. 1997; } 10 \text { (2): 80-7. }\end{array}$ & Impaired Skin Integrity (DC) \\
\hline $\begin{array}{l}16 \text { - Freitas MC, Guedes MVC, Silva LF. Diagnósticos de enfermagem em pós-operatórios de cirurgias } \\
\text { traumato-ortopédicas. Rev.bras.enferm.1997; } 5 \text { (2): 439-48. }\end{array}$ & Impaired Skin Integrity (DC) \\
\hline
\end{tabular}

(The Figure 1 continue in the next page...) 


\section{Articles, authors, periodicals}

DCs/RFs - diagnosis

17- Cuddigan J. Carl I. Clarke M. Maklebust J. Ratliff J. Johnson J. Sparks S. Droste L. Sieggreen M. Wieseke A. Twibell R. Impaired Tissue Integrity. classification of nursing diagnoses: proceeding of the 12 conference/ North American Nursing Diagnosis Association.

18 - Schue RM, Langemo DK. Pressure ulcer prevalence and incidence and a modification of the Braden Scale for a rehabilitation unit. J Wound Ostomy Continence Nurs. 1998; 25(1): 36-43.

19 - Faro ACM. Fatores de risco para úlcera de pressão: subsídios para a prevenção. Rev.esc.enfem USP. 1999; 33(3):279-83.

20 - Rossi LA, Torrati FG, Manfrim A, Silva DF. Diagnósticos de enfermagem do paciente no período pósoperatório imediato. Rev. esc. enf. USP. 2000; 34(2): 154-64.

21 - Murdoch V. Pressure care in the pediatrics intensive care unit. Nurs Stand. 2002; 17(6):71-6.

22 - Guerreiro ALS, Almeida FA, Guimarães HCQCP. Diagnósticos de enfermagem infantil no primeiro pósoperatório de cirurgia cardíaca. Acta paul. enferm. 2003; 16(1): 14-21.

23 - Cafer CR, Barros ALBL, Lucena AF, Mahl MLS, Michel JLM. Diagnósticos de enfermagem e proposta de intervenções para pacientes com lesão medular. Acta paul. enferm. 2005; 18(4): 347-53.

24 - Costa JN, Oliveira MV. Fenômenos de enfermagem em portadores de lesão medular e o desenvolvimento de úlceras por pressão. Rev. Enferm. UERJ. 2005; 13(3): 367-73

25 - Dalri CC, Rossi LA, Dalri MCB. Diagnósticos de enfermagem de pacientes em período pós-operatório imediato de colecistectomia laparoscópica. Rev. Latino-Am. Enfermagem. 2006; 14(3): 389-96.

26 - Noonan C, Quigley S, Curley MAQ. Skin integrity in hospitalized infants and children a prevalence survey. Journal of Pediatric Nursing. 2006; 21(6): 445-53.

27 - Silvia VM, Oliveira TC, Guedes NG, Moreira RP, Cavalcante TF. Estabelecimento dos diagnósticos de pacientes com diabetes mellitus. In Elizalva FO; Maria Mirian LN; Maria Julia GOS, organizadores. Trilhando caminhos na construção de uma terminologia brasileira de enfermagem. 8th National Symposium of Nursing Diagnoses (Sinaden); 23-26th May 2006; João Pessoa, Paraíba. João Pessoa: UFPB; 2006. CD ROM 28 - Morias AKJ, Lopes Neto A, Andrade JS, Vieira MJ. Diagnósticos de enfermagem em pacientes cirúrgicos. In Elizalva FO; Maria Mirian LN; Maria Julia GOS, organizers. Trilhando caminhos na construção de uma terminologia brasileira de enfermagem. 8th National Symposium of Nursing Diagnoses (Sinaden); 23-26th May 2006; João Pessoa, Paraíba. João Pessoa: UFPB; 2006. CD ROM.

29 - Silvia CC, Lucena KD, Vieira MSE, Passos RS, Rocha VC, Gomes SKA. Sistematização da assistência de enfermagem a uma cliente acometida por acidente vascular encefálico. In: Elizalva FO; Maria Mirian LN; Maria Julia GOS, organizers. Trilhando caminhos na construção de uma terminologia brasileira de enfermagem. 8th National Symposium of Nursing Diagnoses (Sinaden); 23-26th May 2006; João Pessoa, Paraíba. João Pessoa: UFPB; 2006. CD ROM.

30 - Bassoli, SRB, Guimarães HCQC, Virmond MCL. Identificação dos diagnósticos de enfermagem em uma clínica dermatológica. In Elizalva FO; Maria Mirian LN; Maria Julia GOS, organizers. Trilhando caminhos na construção de uma terminologia brasileira de enfermagem. 8th National Symposium of Nursing Diagnoses (Sinaden); 23-26th May 2006; João Pessoa, Paraíba. João Pessoa: UFPB; 2006. CD ROM.

31 - Baldissera VDA, Nogueira AMA, Fernandes FO, Araújo RD. Diagnósticos de enfermagem relacionados a complicação periostomal segundo NANDA: análise crítica das habilidades necessárias ao enfermeiro. Arq. Ciênc. Saúde Unipar. 2007; 11(1): 63-0.

32 - Schindler CA, Mikhailov TA, Fischer K, Lukasiewicz G, Kuhn EM, Duncan L. Skin integrity in critically ill and injured children. American journal of critical care. 2007; 16(6):568-74.

33 - Collen TB Pediatric Skin Care: Guidelines for Assessment, Prevention, and Treatment. Dermatology Nursing. 2007:19(5):471-85.

34 - Galiza FT, Bastos NP, Teixeira SC, Freitas MC, Gudes, MVC, Gomes LDP. Risco de integridade da pele prejudicado no idoso: Cuidado clínico de enfermagem. Contribuição Brasileira para o desenvolvimento das Classificações de Enfermagem. 9th National Symposium of Nursing Diagnoses (Sinaden); 26-29th May 2008 Porto Alegre, Rio Grande do Sul: HC Porto Alegre; 2008. $n^{\circ}$ 42. CD ROM.

35 - Zamberlan, C. O cuidado da enfermagem em pacientes com úlcera de pressão. Contribuição Brasileira para o desenvolvimento das Classificações de Enfermagem. 9th National Symposium of Nursing Diagnoses (Sinaden); 26-29th May 2008; Porto Alegre, Rio Grande do Sul: HC Porto Alegre; 2008. n 32. CD ROM.

36 - Malaquias SG, Bachion. MM, Nakatani, AYK. Avaliação da ocorrência de risco de integridade da pele prejudicada em idosos hospitalizados. Contribuição Brasileira para o desenvolvimento das Classificações de Enfermagem. 9th National Symposium of Nursing Diagnoses (Sinaden); 26-29th May 2008; Porto Alegre, Rio Grande do Sul: HC Porto Alegre; 2008. $n^{\circ}$ 39. CD ROM

37 - Carpenito-Moyet LJ. Manual de Diagnósticos de Enfermagem. 11ed. São Paulo: Artmed, 2008. 306p.

38 - Diagnósticos de enfermagem da NANDA: Definições e Classificação 2009-2011/NANDA Internacional; translation Regina Machado Garcez. Porto Alegre: Artmed; 2010. 456p.

The three NDs under study (DC/RF)

Impaired Skin Integrity (RF)

Impaired Skin Integrity (RF)

The three NDs under study (DC/RF)

Impaired Skin Integrity (RF)

Impaired Skin Integrity (RF/DC)

Impaired Skin Integrity (RF/DC)

Impaired Skin Integrity (DC/RF)

Impaired Tissue Integrity (DC)

Impaired Skin Integrity (DC/RF)

Impaired Skin Integrity (DC)

Impaired Skin Integrity (DC)

Impaired Skin Integrity (DC)

Impaired Skin Integrity (DC/RF)

Impaired Skin Integrity (DC)

Impaired Skin Integrity (RF)

Impaired Skin Integrity (RF)

Impaired Skin Integrity (RF)

Impaired Skin Integrity (DC)

Impaired Skin Integrity (RF)

The three NDs under study (DC/RF)

The three NDs under study (DC/RF)

Figure 2 - List of articles selected according to author, periodical and diagnoses studied

After closing the article search, the DCs and RFs were identified and organized into a list. At this point, each one's operational definition (OD) was constructed, using literature relevant to the issue. After this, the content validation was carried out.

Six nurses with known expertise in the areas of dermatology and stomal therapy were intentionally invited to be the judges in validating the ODs. All were female, with an average age of 46 years ( 38 to 49 years) and an average professional experience of 22.8 years (13 to 26 years).

The judges stated that: they were experienced with 
nursing diagnosis, two of them (33\%) worked in both areas (dermatology and stomal therapy), three (50\%) worked only with dermatology and one (17\%) worked only with stomal therapy. Regarding their qualifications, four $(66.6 \%)$ were PhDs, one had an M.A, and one was a specialist.

The definitions of the diagnoses proposed by NANDA-I and the operational definitions elaborated by the researchers were evaluated for relevance, clarity and comprehensiveness, according to the model used in a previous study ${ }^{(8)}$.

The relevance indicated that the OD elaborated was in line with the DC/RF of the diagnosis studied. Each item was evaluated as: $(-1)$ not relevant; $(0)$ not possible to evaluate/don't know; and (+1) relevant.

The clarity referred to the fact of the OD being clear and easy to understand, principally by nurses who are not specialists on the subject. Thus, the operational definitions were evaluated as: $(-1)$ not clear; (0) not possible to evaluate/don't know and $(+1)$ clear.

The comprehensiveness referred to the OD being sufficiently broad and comprehensive for the DC/ RF studied. For the evaluation of comprehensiveness, each item was evaluated as: $(-1)$ not comprehensive; (0) not possible to evaluate/don't know, and (+1) comprehensive. In addition to this, the judges were requested to ascertain if there was any redundancy between DCs/RFs, or if there was any need for additions.

Excel (version 2007 Microsoft), was used for tabulation and analysis of the data. The percentage agreement was used for calculating the content validity, a method used for calculating agreement between the judges. This is calculated based on the number of participants who agree, divided by the total number of participants and multiplied by $100^{(9)}$. A percentage agreement equal to or greater than $80 \%$ is considered adequate, that is, five of the six judges would have to agree on the definition presented, as recommended in the literature(10).

The project was approved by the Research Ethics Committee of the Dr. Mário Gatti hospital under protocol number 029/2010.

\section{Results}

As may be observed in Figure 2, 72.2\% (26/36) of the articles dealt either with diagnoses of Impaired Skin Integrity or Risk for Impaired Skin Integrity, while $16.7 \%(6 / 36)$ discussed both these diagnoses jointly, $8.3 \%(3 / 36)$ addressed all three diagnoses, and only one $(2,8 \%)$ referred to the diagnosis of Impaired Tissue Integrity. The two books consulted presented the three diagnoses' DC/RF.

Of the articles, 53\% (19/36) were international, $14 \%(5 / 36)$ were studies on validation of diagnoses of Impaired Skin Integrity and Risk for Impaired Skin Integrity published in 1989 and 1992. No study was found on validation of the diagnosis of Impaired Tissue Integrity, and the others were on the incidence and prevalence of these diagnoses among varying populations.

The most commonly used methods $(60 \%$ or $3 / 5)$ were content validation and clinical validation ${ }^{(2)}$ and the nurses who participated in the studies, as experts, were those with professional registration. Only one study adopted as a criteria being an intensive care nurse, a member of the American Association of Critical Care Nurses. The other two were clinical, with data collected from medical records and retrospective validation of the diagnosis $^{(11)}$

Practically all the studies selected presented other DCs and RFs, in addition to those described by NANDA-I - such as, for example, hyperemia, pain, cellulitis and blisters. Only one presented the ODs used, but without informing whether they were validated or not.

Regarding the result of the validation of the definitions of the diagnoses by the six judges, the definition of the diagnosis of Impaired Skin Integrity obtained a percentage agreement of $83 \%$, and the judges made no suggestions for modifying it.

Although the diagnosis of Risk for Impairment of Skin Integrity also received a percentage agreement of $83 \%$, the judges suggested that its definition be modified from "at risk for skin being adversely altered" to "Risk of loss of skin integrity".

The definition of the diagnosis "Impaired Tissue Integrity" presented a percentage agreement of $83 \%$, and the judges suggested modifying it. Thus, the original definition of "damage to mucous membrane, corneal, integumentary, or subcutaneous tissues" was modified by the researchers to: "damage to the mucous membranes (oral, nasal, ocular, anal, urethral or vaginal), ocular cornea, skin, subcutaneous tissue (hypodermis), muscular fascia, muscle, tendons and bone".

After further evaluation by the judges, one suggested removing the word "skin", and the definition became: "damage to the mucous membranes (oral, nasal, ocular, anal, urethral or vaginal), ocular cornea, subcutaneous tissue (hypodermis), muscular fascia, muscle, tendons and bone". 
As the skin is also involved when Tissue Integrity is impaired, the researchers decided to keep the two definitions, in addition to the original proposed by NANDA-I, so that they might be validated by future studies.

Regarding the operational definitions of the defining characteristics of the diagnosis of Impaired Skin Integrity, $22(46 \%)$ obtained a percentage agreement over $80 \%$, and 26 (54\%) obtained a percentage agreement of less than $80 \%$.

The diagnosis of Risk for Impaired Skin Integrity had 37 (48\%) operational definitions of the risk factors with a percentage agreement over $80 \%$, and 40 (52\%) with a percentage agreement of less than $80 \%$.

The diagnosis of Impaired Tissue Integrity presented 10 (48\%) operational definitions of DCs with a percentage agreement over $80 \%$ and 11 (52\%) with less than $80 \%$.

In the face of these results, the operational definitions were revised and modified in line with the judges' suggestions and the literature review, and were again submitted for the judges' evaluation. Four judges participated in this new evaluation.
In this second evaluation, adjustments were necessary only for three ODs of the diagnosis of Impaired Skin Integrity, 19 ODs of the diagnosis of Risk for Impaired Skin Integrity, and 7 ODs of the diagnosis of Impaired Tissue Integrity. These adjustments - due either to percentage agreements below $80 \%$, or to suggestions for modifications put forward by the judges - were carried out by the researchers. The remaining ODs obtained percentage agreements of $100 \%$.

The ODs being considered adequate - that is, having achieved a percentage agreement of over $80 \%$ - it was therefore decided to cease the validation process at this point. The few that had not achieved this percentage were modified as suggested.

Regarding the presence of redundant DCs/RFs, the judges identified 13 DCs for the diagnosis of Impaired Skin Integrity and 9 RFs for the diagnosis of Risk for Impaired Skin Integrity. Of the 146 defining characteristics/risk factors, 22 were considered redundant and excluded.

Thus, 35 DCs for the diagnosis of Impaired Skin Integrity, 68 RFs for the diagnosis of Risk for Impaired Skin Integrity, and 21 DCs for the diagnosis of Impaired Tissue Integrity remained, as may be seen in Figures 3, 4 and 5.

\begin{tabular}{|l|l|l|}
\hline 1 - Destruction of layers of the Skin & 13 - Erythema & 25 - Drainage \\
\hline 2 - Disruption of skin layers & 14 - Desquamation & 26 - Cellulitis \\
\hline 3 - Break in the surface of the skin & 15 - Pruritis & 27 - Edema \\
\hline 4 - Unprotected skin & 16 - Urticaria & 28 - Hematoma \\
\hline 5 - Skin maceration & 17 - Primary lesions & 29 - Altered feeling \\
\hline 6 - Excoriation & 18 - Secondary lesions & 30 - Slow scarring \\
\hline 7 - Invasion of body structures & 19 - Pressure ulcer/Decubitus ulcer & 31 - Decreased capillary refill \\
\hline 8 - Exposed subcutaneous tissue & 20 - Bedsore & 32 - Alteration of body temperature \\
\hline 9 - Exposed muscle and tendons & 21 - Necrotic tissue & 33 - Numbness \\
\hline 10 - Exposed bone & 22 - Burns & 34 - Pain \\
\hline 11 - Alteration of skin color & 23 - Inflammation & 35 - Limited mobility \\
\hline 12 - Dry skin & 24 - Abscess & \\
\hline
\end{tabular}

Figure 3 - Defining characteristics of the diagnosis of Impaired Skin Integrity, validated by the judges

\begin{tabular}{|c|c|c|}
\hline 1 - Damp skin & 24 - Changes in metabolic state & 47 - Alterations in consciousness level \\
\hline 2 - Conditions of skin (maceration) & 25 - Development factors & 48 - Use of incontinence pads \\
\hline 3 - Skin structures broken & 26 - Unbalanced nutritional status (obesity) & 49 - Family support \\
\hline 4 - Changes in the skin's turgor & 27 - Unbalanced nutritional status (weight loss) & 50 - Peripheral vascular disorder/impairment \\
\hline 5 - Drying of the skin & 28 - Nutritional status (dehydration) & 51 - Impaired circulation \\
\hline 6 - Little thickness of skin & 29 - Diastolic blood pressure below $60 \mathrm{mmHg}$ & $\begin{array}{l}52 \text { - Alteration in levels of hemoglobin and } \\
\text { hematocrit }\end{array}$ \\
\hline 7 - Changes in pigmentation & 30 - Diabetes Mellitus & 53 - Decrease in serum albumin \\
\hline 8 - Excretions & 31 - Neurological illness & 54 - Immunosupression \\
\hline 9 - Chemical substance & 32 - Cardiopulmonary disorders & 55 - Fecal incontinence \\
\hline 10 - Radiation & 33 - Medical diagnosis & 56 - Urinary incontinence \\
\hline 11 - Infection & 34 - Cancer & 57 - Pressure relief device \\
\hline 12 - Edema & 35 - Smoking & 58 - Length of hospitalization \\
\hline 13 - Anemia (hemoglobin below 10 ) & 36 - Extremes of age & 59 - Behavioral Interventions \\
\hline
\end{tabular}

(The Figure 4 continue in the next page...) 


\begin{tabular}{|l|l|l|}
\hline 14 - Psychogenic factors & 37 - Self-care alteration & 60 - Social competence \\
\hline $\begin{array}{l}15 \text { - Medications (diuretics, sedatives, } \\
\text { analgesics, vasopressor drugs) }\end{array}$ & 38 - Environmental variables & 61 - Sensory perception \\
\hline 16 - Mechanical factors such as abrasive forces & 39 - Activity & 62 - Reduction in oxygenation \\
\hline 17 - Mechanical factors such as pressure & 40 - Hyperthermia & 63 - Hypovolemia \\
\hline 18 - Mechanical factors such as contention & 41 - Hypothermia & 64 - Race \\
\hline 19 - Bony prominences & 42 - Physical immobility & 65 - Secretion \\
\hline 20 - Shearing force & 43 - Altered physical mobility & 66 - Immunological factors \\
\hline 21 - Friction & 44 - Alterations in level of consciousness & 67 - Altered sensitivity \\
\hline 22 - Blister in region of bony prominence & 45 - Being confined to bed or a chair & 68 - Humidity \\
\hline 23 - Previous history of pressure ulcers & 46 - Impaired feeling & \\
\hline
\end{tabular}

Figure 4 - Risk factors for the diagnosis of Risk for Impaired Skin Integrity, validated by the judges

\begin{tabular}{|l|l|l|}
\hline 1 - Tissue destroyed & 8 - Surgical incision & 15 - Cellulitis \\
\hline $\begin{array}{l}2 \text { - Damaged tissue (for example, cornea, } \\
\text { mucosa, skin or subcutaneous tissue) }\end{array}$ & 9 - Dry mucosa & 16 - Exposure of subcutaneous tissue \\
\hline $\begin{array}{l}3 \text { - Rupture of mucosal tegumentary or corneal } \\
\text { tissue }\end{array}$ & 10 - Coated tongue & 17 - Exposure of muscle and tendon \\
\hline 4 - Primary lesions & 11 - Leucoplakia & 18 - Exposure of bone \\
\hline 5 - Secondary lesions & 12 - Ulceration & 19 - Destruição mecânica dos tecidos \\
\hline 6 - Edema & 13 - Pressure ulcer/decubitus ulcer & 20 - Bedsore \\
\hline 7 - Erythema & $\begin{array}{l}14 \text { - Elementary lesion secondary to loss of } \\
\text { substance }\end{array}$ & 21 - Surgical procedure \\
\hline
\end{tabular}

Figure 5 - Defining characteristics for the diagnosis of Impaired Tissue Integrity, validated by the judges

\section{Discussion}

The literature review shows that nurses have researched and published much more on the subject of the diagnoses of Impaired Skin Integrity and Risk of Impaired Skin Integrity(12-16) than on the diagnosis of Impaired Tissue Integrity.

This fact reflects nurses' clinical practice, as when the diagnosis of Impaired Tissue Integrity appears little in the studies of incidence and prevalence of nursing diagnoses, this may mean that either the nurse has not identified this diagnosis in clinical practice, or that it is being diagnosed as Impaired Skin Integrity and treated as such. This last supposition is corroborated by a study on pressure ulcers ${ }^{(17)}$, in which the diagnosis of Impaired Skin Integrity was present but that of Impaired Tissue Integrity was not.

However, this reality may be changing, as in a recent study on clinical profiles and nursing diagnoses of patients at risk of pressure ulcers ${ }^{(18)}$, the diagnosis of Impaired Tissue Integrity was the eleventh most frequent, with $13 \%$.

The low number of articles on Impaired Tissue Integrity made its analysis difficult, but allowed the identification of a knowledge gap in relation to the same, which indicates the need for developing further studies on this diagnosis.
Another aspect which attracted attention was the low number of studies on the validation of these diagnoses and the period in which they were carried out, that is, in the 1990s, even with the suggestion by some of these studies' authors that other research involving the issue be undertaken ${ }^{(12-16)}$. However, this scenario has changed, as new studies were found on validation and the occurrence of these diagnoses, undertaken in 2010 and 2011(5-6) in Brazil, in addition to the present investigation.

Varying numbers of DCs/RFs were found, different from those presented by NANDA-I, as under that taxonomy the diagnosis of Impaired Skin Integrity has only three DCs, the diagnosis of Risk for Impaired Skin Integrity presents 22 RFs, and the diagnosis of Impaired Tissue Integrity has two $\mathrm{DCs}^{(4)}$.

This result confirms what had already been indicated by the literature, as all the articles selected presented DCs and RFs different from NANDA-I. This may be interpreted to mean that the studies' results evidence that nurses, in their care practice, have used DCs and RFs which are not described or approved by NANDA-I to establish the diagnoses referred to.

In relation to the process of validation of the ODs, in the first evaluation it was not possible to validate all of them, it being necessary to undertake a further revision of, and further adjustments to, the operational 
definitions, prior to submitting them to a second evaluation by the judges. This is perfectly acceptable in this type of study, as it is very difficult to achieve consensus among all the judges in the first round. The modifications made improved the qualification of the operational definitions, assisting the validation process.

One very important aspect in this process of the validation of the ODs was the suggestion made by the judges to modify the definitions of the diagnoses of Risk for Impaired Skin Integrity and Impaired Tissue Integrity, as, if the process of change really should be carried through after other studies, this will be reflected directly in nurses' clinical practice, because more precise definition of these diagnoses would permit them to distinguished from the others.

Further, a higher number of DCs/RFs representing these diagnoses will probably allow them to be identified more accurately, although caution is necessary here because when DCs/RFs are shared by more than one diagnosis, the fact may create doubts; in addition to this, an excessively high number of DCs/RFs may lead to a less accurate diagnosis, when in a specified clinical situation, only secondary DCs or RFs are identified.

\section{Conclusion}

It was possible to identify various defining characteristics and risk factors which are not present in the NANDA-I taxonomy but which were indicated by the literature.

The use of a rigorous methodology for evaluating and refining allowed the construction of operational definitions for DCs/RFs which were relevant, clear and comprehensive, as well as the proposing of new definitions for two diagnoses, Impaired Tissue Integrity and Risk for Impaired Skin Integrity, which will be evaluated in future studies.

By presenting clearer definitions for these diagnoses, and a higher number of DCs/RFs, the hope is to assist nurses in identifying them with greater accuracy in clinical practice.

This study's contribution consists of presenting clearer operational definitions and a higher number of DCs/RFs, which may assist nurses in the identification and use of the same with greater accuracy in clinical practice.

\section{References}

1. Gordon M. Implementation of nursing diagnoses: na overview. Nurs Clin North Am.1987;22(4):875-9.
2. Fehring RJ. The Fehring Model. In: Carrol-Johnson, RM; Paquete M. ed. Classification of nursing diagnoses: Proceedings of the Tenth conference. Philadelphia: JB Lippincott; 1994. p. 55-62.

3. Pompeo DA, Rossi LA, Galvão MC. Revisão Integrativa: etapa inicial de processo de validação de diagnóstico de enfermagem. Acta Paul Enferm. 2009;22(4):434-8.

4. Diagnósticos de enfermagem da NANDA: Definições

e Classificação 2009-2011/NANDA Internacional; tradução Regina Machado Garcez. Porto Alegre: Artmed; 2010. 456 p.

5. Malaquias GS. Validação clínica de Integridade da Pele de área perilesional e Integridade Tissular Prejudicada relacionada à circulação alterada em pessoas com úlceras vasculogênicas. [dissertação]. Goiânia: Universidade Federal de Goiás; 2010.

6. Costanzi PA. Validação clínica dos diagnósticos de Mobilidade Física Prejudicada, Integridade Tissular Prejudicada e Integridade da Pele Prejudicada, e em pacientes submetidos a cateterismo cardíaco. [dissertação]. Porto Alegre: Escola de Enfermagem da Universidade Federal do Rio Grande do Sul; 2011.

7. Carpenito-Moyet LJ. Manual de Diagnósticos de Enfermagem. 11ed. São Paulo: Artmed; 2008. 306 p.

8. Silva VA. Associação entre incontinência urinária de fragilidade em idoso em atendimento ambulatorial. [dissertação]. Campinas: Faculdade de Ciências Médicas da Universidade Estadual de Campinas; 2010.

9. Alexandre NMC, Coluci MZO. Validade de conteúdo nos processos de construção e adaptação de instrumentos de medidas. Ciência e Saúde Coletiva [periódico na Internet]. 2011[acesso 26 set 2011]; 16(7):30618. Disponível em: http://dx.doi.org/10.1590/S141381232011000800006 .

10. Lenny MR. Determination and quantification of content validity. Nurs Res. 1986;35(6):382-5.

11. Gordon M, Sweeney MA. Methodological problems and issues in identifying and standardizing nursing diagnosis. Adv Nurs Sci. 1979;2(1):1-15.

12. Lewis-Abney K, Rosenkranz CF. Content validation of impaired skin integrity and urinary incontinence in the home health setting. Nurs Diag. 1992;5(1):36-42.

13. Wieseke A, Twibell KR, Bennett S, Marine M, Schoger J. A content validation study of five nursing diagnoses by critical care nurses. Heart \& Lung. 1994;23(4):345-51. 14. Levin FR, Krainovitch CB, Bahrenburg E, Mitchell CA Diagnostic content validity of nursing diagnoses. Image J Nurs Sch. 1989;21(1):40-4.

15. Anderson J, Thomson A. Impaired skin integrity: clinical validation of the defining characteristics. In 
Classification of nursing diagnoses: proceedings of the ninth conference held in Orlando, FL, 1990. CarrollJohnson RM; JB Lippincott; 1991. p. 126-32.

16. Schappler N. Impaired skin integrity: actual and potential in orthopedic patients. In: Classification of nursing diagnoses: proceedings of the eight conference held in St. Louis, MO, March, 1988. Carroll-Johnson RM; JB Lippincott; 1989. p. 345-8.

17. Costa JN, Oliveira MV. Fenômenos de enfermagem em portadores de lesão medular e o desenvolvimento de úlcera por pressão. Rev Enferm UFRJ. 2005;13(3):367-73.

18. Lucena AF, Santos CT, Pereira AGS, Almeida AA, Dias VLM, Friedrich MA Perfil clínico e diagnósticos de enfermagem de pacientes em risco para úlcera por pressão. Rev. Latino-Am. Enfermagem. 2011;19(3):523-30. 